Fitofarmaka, Vol 3, No. 2, Desember 2013 ISSN: 2087-9164

\title{
AKTIVITAS ANTIOKSIDAN EKSTRAK ETANOL DAN FRAKSI-FRAKSI DAUN EKOR KUCING (Acalypha hispida Burm. F)DENGAN METODE PENGHAMBATAN REDUKSI WATER SOLUBLE TETRAZOLIUM SALT-1
}

(WST-1)

\author{
Maya Febriyanti, Beylan W. Sanjaya, Supriyatna, Ajeng Diantini, Anas Subarnas \\ Fakultas Farmasi Universitas Padjadjaran, Jatinangor - Sumedang \\ Email : maya.febriyanti@gmail.com
}

\begin{abstract}
ABSTRAK
Radikal bebas merupakan salah satu penyebab terjadinya berbagai macam penyakit degeneratif seperti kanker, jantung koroner dan penuaan dini. Oleh karena itu dibutuhkan suatu antioksidan untuk meredam radikal bebas tersebut. Ekor kucing (Acalypha hispida Burm.f.) merupakan salah satu jenis tanaman obat yang memiliki aktivitas antioksidan. Tanaman ini telah diteliti sebelumnya dan menunjukkan bahwa fraksi $n$-heksan dari ekstrak metanol yang diperoleh melalui metode kromatografi telah dilakukan uji aktivitas free radical scavenging menggunakan metode DPPH. Dalam penelitian ini dilakukan pengujian aktivitasantioksidanekstraketanoldanfraksifraksi dari daun ekor kucing dengan metode penghambatan reduksi Water Soluble Tetrazolium Salt (WST-1).Aktivitas peredaman anion superoksida diukur dengan menggunakan perangkat uji superoksida dismutase (SOD). Hasil pengujian aktivitas antioksidan menunjukkan bahwa fraksi etil asetat memberikan persentase penghambatan terbaik dibandingkan ekstrak etanol, fraksi n-heksan dan air dengan persentase penghambatan sebesar 63.14\% (10 $\mu \mathrm{g} / \mathrm{ml}), 91.95 \%(100 \mu \mathrm{g} / \mathrm{ml})$ dan $100 \%$ $(1000 \mu \mathrm{g} / \mathrm{ml})$. Senyawa yang teridentifikasi dalam fraksi etil asetat adalah flavonoid, kuinon, polifenol dan tanin. Jika dibandingkan dengan asam askorbat, fraksi etil asetat memiliki aktivitas antioksidan (SOD like activity) yang lebih tinggi
\end{abstract}

Kata kunci: radikal bebas, Acalypha hispida, superoksida dismutase (SOD)

\begin{abstract}
Free radicals are one of the causes of a variety of degenerative diseases such as cancer, coronary heart disease and ageing. Therefore it takes an antioxidant to scavenge free radicals.Acalypha hispida Burm.f.is one of medicinal plants that has an antioxidant activity. This plant has been studied previously and showed that the nhexane fractions from the methanol extract obtained from chromatographic separation had antioxidant activity in the DPPH method. In this study the antioxidant activity of the ethanol extract and fractions from the leaves ofA.hispida were evaluated with the inhibition ofWater Soluble Tetrazolium Salt (WST-1) reduction method. Scavenging activities of superoxide anion was measured using superoxide dismutase(SOD)assay kit.The results showed that the antioxidant activity of the ethyl acetate fraction gave the best inhibition percentages than ethanol extract, n-hexane fraction and water fraction with a percentage inhibition of $63.14 \%(10 \mathrm{ug} / \mathrm{ml}), 91.95 \%(100 \mathrm{ug} / \mathrm{ml})$ and $100 \%(1000 \mathrm{mg} / \mathrm{ml})$. The compounds identified in the ethyl acetate fraction were flavonoids, quinones, polyphenols and tannins. As compared with ascorbic acid, the ethyl acetate fraction had higher antioxidant activity (SOD like activity).
\end{abstract}

Key word: free-radical, Acalypha hispida, superoxide dismutase (SOD) 


\section{PENDAHULUAN}

Kondisi dunia yang semakin maju
dengan berbagai teknologi telah mendorong penghuninya menjadi manusia modern. Pola hidup manusia yang modern membuat tubuh kita secara terus-menerus membentuk radikal bebas akibat dari polusi lingkungan, sinar ultraviolet dan asap rokok. Akibat yang ditimbulkan oleh lingkungan tercemar, kesalahan pola makan dan gaya hidup, justru merangsang tumbuhnya radikal bebas yang dapat merusak tubuh kita, serta proses penuaan berdasarkan timbulnya kerusakan jaringan yang disebabkan oleh radikal bebas (Parwata, 2010).

Radikal bebas kini dianggap berperan dalam patogenesis sebagian besar penyakit. Antioksidan adalah zat kimia yang menawarkan elektron mereka sendiri untuk radikal bebas, sehingga mencegah kerusakan sel. Banyak penelitian telah menunjukkan senyawa fitokimia dengan aktivitas antioksidan dapat mengurangi resiko kanker dan penyakit jantung. Oleh karena itu, diperlukan asupan antioksidan untuk mengurangi kerusakan sel dan proses penuaan (Potterat, 1997).

Ekor kucing (Acalypha hispida Burm. F) merupakan tanaman hias yang tumbuh hampir diseluruh dunia. Skrining fitokimia terhadap ekstrak air dan ekstrak metanol A.hispida menunjukkan adanya senyawa fenolik, flavonoid, glikosida, steroid, phlobatanin, dan hidroksi antraquinon (Okondoruet al, 2009). Ekstrak $n$-heksanaA. Hispida diketahui mengandung senyawa golongan alkaloid, karbohidrat, fenol, dan alkaloid.Uji toksisisitas juga dilakukan terhadap ekstrak A. hispida menggunakan metode BSLT. Pengujian menunjukkan bahwa ekstrak A. hispida bersifat sitotoksik terhadap A. salina dengan $\mathrm{LC}_{50} 4,375$ $\mu \mathrm{g} / \mathrm{ml}$ (Onocha et al., 2011). Asam galat, corilagin, cycloartane-type triterpenoids, flavonoid misalnya kuersetin, dan derivat kaempferol juga telah diisolasi dari tumbuhan A.hispida (Adesina et al, 2000; Gutierrez-Lugo et al, 2002).

Aktivitas antioksidan A. hispida juga telah diuji oleh Onocha et al (2011). Fraksi $n$-heksan dari ekstrak metanol $A$. hispida yang diperoleh melalui metode kromatografi telah dilakukan uji aktivitas free radical scavenging menggunakan 2,2-diphenyl-1-picrylhydrazyl radical (DPPH). Dari 16 fraksi (S1-S16) yang dikumpulkan, persentase inhibisi senyawa S10 (91.8 \%), S11 (93.8\%), S14 (92.5 \%) dan S15 (91.4\%) dengan konsenstrasi0.1 $\mathrm{mg} / \mathrm{ml}$ memberikan aktivitas antioksidan yang lebih baik dibandingkan terhadap persentase inhibisi asam askorbat (90.9\%). Aktivitas antioksidan tersebut dapat dihubungkan dengan metabolit sekunder yang terdapat pada $A$. hispida yaitu flavonoid dan fenol (Onocha, et al., 2011).

Berdasarkan penelitian ini, potensi tumbuhan ekor kucing (Acalypha hispida Burm. F) sebagai sumber antioksidan alami perlu diteliti lebih lanjut terhadap parameter pengujian aktivitas antioksidan yang lain.

\section{METODE PENELITIAN}

\section{Bahan tanaman: Daun Ekor Kucing}

Bahan Kimia: Amil alkohol, aquadest, asam klorida, asam asetat, asam sulfat, besi (III) klorida, dimetil sulfoksida (DMSO), etanol 70\%, etil asetat, metanol, natrium klorida, n-heksana, kalium hidroksida, kloroform, gelatin, Kalium iodida, Bismuth subnitrat, raksa (II) klorida, vanillin, SOD assay kit-WST (Dojindo Molekular Technologies, Inc.).

Alat : corong pisah, maserator, 96-well mikroplate reader $450 \mathrm{~nm}$ (Dynex technologi),mikropipet (Finnipipette), rotary evaporator (Heidolph-Bibby), timbangan analitik (AND EK-300i), waterbath, serta berbagai alat gelas yang biasa digunakan di Laboratorium Farmakologi, Laboratorium Kimia Bahan Alam, Unit Penelitian dan Pengabdian 
Fitofarmaka, Vol 3, No. 2, Desember 2013 ISSN: 2087-9164

kepada Masyarakat Farmasi (UPT UPPF)

Fakultas Farmasi Universitas

Padjadjaran.

\section{Metode}

\section{Ekstraksi}

Ekstraksi menggunakan metode maserasi selama 3 x 24 jam dengan cairan penyari etanol $70 \%$.Proses ekstraksi dilakukan dengan cara maserasi terhadap 450 gram simplisia daun A.hispidayang telah diblender menjadi potonganpotongan halus. Maserasi dilakukan dengan menggunakan pelarut etanol $70 \%$ dan dilakukan selama $3 \times 24$ jam. Ekstrak etanol hasil maserasi dipekatkan menggunakan rotavapor pada suhu $50^{\circ} \mathrm{C}$.

\section{Fraksinasi}

Proses fraksinasi dilakukan dengan cara ECC (Ekstraksi Cair-Cair) menggunakan pelarut air, n-heksana dan etil asetat. Ekstrak kental hasil maserasi diambil sebanyak 30 gram dan dilarutkan dalam $400 \mathrm{ml}$ air yang selanjutnya akan dilakukan pemisahan menggunakan corong pisah dengan pelarut yang tidak saling bercampur satu sama lain yaitu n-heksana yang dilanjutkan dengan etil asetat dengan perbandingan ekstrak cair $:$ pelarut $=$ $1: 1$.

\section{Penapisan Fitokimia}

Penapisan fitokimia ekstrak etanol, fraksi $n$-heksana, fraksi etil asetat dan fraksi airdaun A.hispida.

\section{Uji aktivitas antioksidan}

Pengujian aktivitas antioksidan dilakukan dengan metode WST-1 menggunakan SOD assay kit-WST (Dojindo Molekular Technologies, Inc.).Pada metode ini reduksi WST-1 menghasilkan senyawa formazan yang berwarna kuning yang dapat diukur absorbansinya dengan mikro plate reader pada panjang gelombang $450 \mathrm{~nm}$ dan persen penghambatan radikal superoksid dihitung dengan menggunakan persamaan :

$$
(A-A
$$

$$
1-\frac{2}{(A-A)} X 100 \%
$$

Keterangan :

As : Absorbansi sampel

Ak : Absorbansi kontrol

$\mathrm{Ab} \quad$ : Absorbansi blanko

\section{HASIL DAN PEMBAHASAN}

Bahan tanaman dikumpulkan dari

Kebun Tanaman Obat Manoko, Lembang, Jawa Barat. Determinasi tumbuhan dilakukan di Herbarium Sekolah Ilmu dan Teknologi Hayati, Institut Teknologi Bandung, Jawa Barat. Rendemen ekstrak beserta fraksinya dan hasil skrining fitokimia dapat dilihat pada Tabel 1 dan Tabel 2.

Tabel 1. Hasil Ekstraksi dan Fraksinasi Daun A.hispida

\begin{tabular}{|c|c|r|c|}
\hline No. & Ekstrak/Fraksi & \multicolumn{1}{c|}{ Berat } & $\begin{array}{c}\text { Rendem } \\
\text { en }\end{array}$ \\
\hline 1. & Ekstak Etanol & 117.47 & $26.10 \%$ \\
\hline 2. & $\begin{array}{c}\text { Fraksi } n- \\
\text { heksana }\end{array}$ & $1.3 \mathrm{~g}$ & $4.33 \%$ \\
\hline 3 & Fraksi etil asetat & $8.53 \mathrm{~g}$ & $28.43 \%$ \\
\hline 4 & Fraksi air & $12.47 \mathrm{~g}$ & $41.56 \%$ \\
\hline
\end{tabular}


Fitofarmaka, Vol 3, No. 2, Desember 2013 ISSN: 2087-9164

Tabel 2. Data Hasil Pemeriksaan Fitokimia Simplisia, Ekstrak Etanol A.hispida dan Fraksi-Fraksinya

\begin{tabular}{|c|c|c|c|c|c|}
\hline \multirow{2}{*}{ Golongan } & \multirow{2}{*}{ Simplisia } & \multirow{2}{*}{$\begin{array}{c}\text { Ekstrak } \\
\text { Etanol }\end{array}$} & n-heksan & Etil Asetat & Air \\
\hline Alkaloid & - & - & - & - & - \\
\hline Flavonoid & + & + & + & + & + \\
\hline Kuinon & + & + & - & + & + \\
\hline Polifenol & + & + & - & + & + \\
\hline Saponin & + & + & - & + & + \\
\hline Steroid & + & + & + & - & - \\
\hline tanin & + & + & - & + & + \\
\hline Triterpenoid & - & - & - & - & - \\
\hline monoterpenoid & - & - & - & - & - \\
\hline sesquiterpenoid & - & - & - & - & - \\
\hline
\end{tabular}

Keterangan $:(+)=$ terdeteksi $;(-)=$ tidak terdeteksi

\section{Hasil Uji Aktivitas Antioksidan}

Aktivitas dibandingkan dengan menghitung $\mathrm{IC}_{50}$ dan dibandingkan terhadap $\mathrm{IC}_{50}$ asam askorbat atau dengan menghitung persentase penghambatan dan dibandingkan terhadap presentase penghambatan asam askorbat. Hasil uji aktivitas antioksidan ekstrak etanol beserta fraksinya dan asam askorbat dapat dilihat pada Tabel 3, Tabel 4 dan Gambar 1.

Tabel 3. Hasil Pengujian Aktivitas Antioksidan Ekstrak Etanol, Fraksi $n$-heksana, Etil Asetat dan Fraksi Air

\begin{tabular}{|c|c|c|c|c|}
\hline \multirow{2}{*}{ Konsentrasi } & \multicolumn{3}{|c|}{$\%$ Penghambatan } \\
\cline { 2 - 5 } & Ekstrak etanol & Fraksi n-heksana & Fraksi etil asetat & fraksi air \\
\hline $10 \mu \mathrm{g} / \mathrm{ml}$ & $11.27 \%$ & $30.51 \%$ & $63.14 \%$ & $60.59 \%$ \\
\hline $100 \mu \mathrm{g} / \mathrm{ml}$ & $15.20 \%$ & $33.90 \%$ & $91.95 \%$ & $83.05 \%$ \\
\hline $1000 \mu \mathrm{g} / \mathrm{ml}$ & $22.06 \%$ & $48.31 \%$ & $100 \%$ & $100 \%$ \\
\hline
\end{tabular}

Tabel 4. Hasil Pengujian Aktivitas Antioksidan Asam askorbat

\begin{tabular}{|c|c|}
\hline Konsentrasi & \% Penghambatan \\
\hline $17,613 \mu \mathrm{g} / \mathrm{ml}$ & $32.54 \%$ \\
\hline $88,065 \mu \mathrm{g} / \mathrm{ml}$ & $57.04 \%$ \\
\hline $176,13 \mu \mathrm{g} / \mathrm{ml}$ & $81.48 \%$ \\
\hline
\end{tabular}




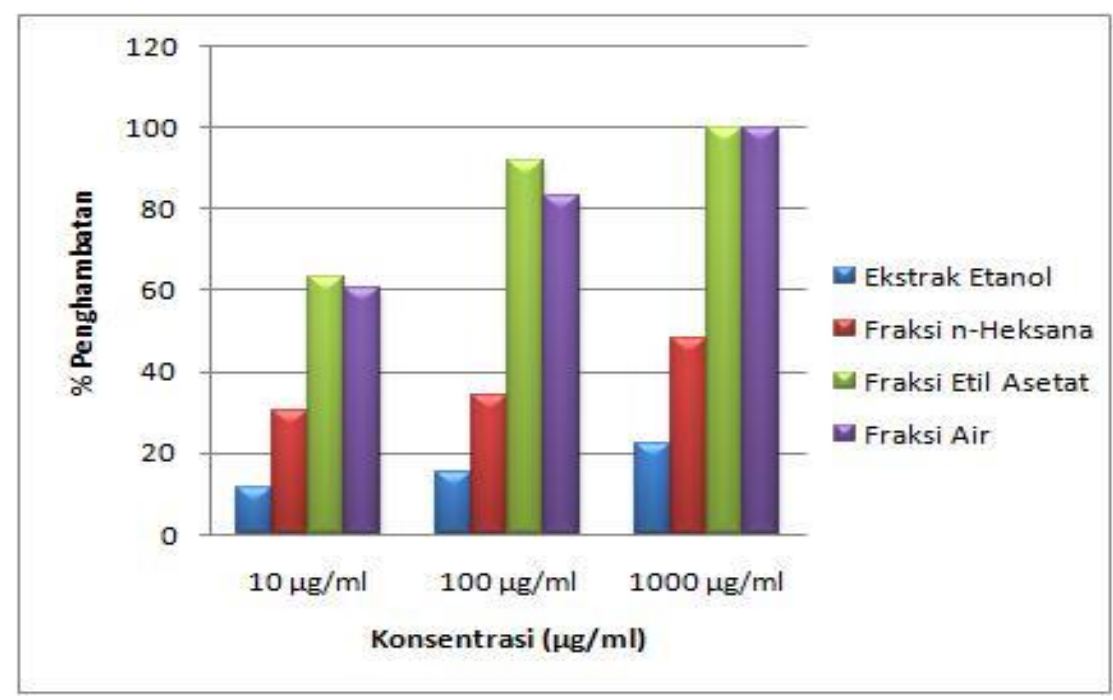

Gambar 1. Hasil Pengujian Aktivitas Antioksidan Ekstrak Etanol, Fraksi $n$-heksan Etil Asetat dan Fraksi A

Pengujian aktivitas antioksidan dilakukan dalam 3 variasi konsentrasi dari ekstrak etanol, fraksi n-heksana, fraksi etil asetat dan fraksi air. Variasi konsentrasi yang digunakan dalam penelitian ini adalah $10 \mu \mathrm{l} / \mathrm{ml}, 100 \mu \mathrm{l} / \mathrm{ml}$ dan $1000 \mu \mathrm{l} / \mathrm{ml}$. Dilihat dari persentase penghambatannya Fraksi etil asetat memiliki aktivitas antioksidan terbaik dengan persentase penghambatan pada konsentrasi $10 \mu \mathrm{g} / \mathrm{ml}$ sebesar 63,14\%, $100 \mu \mathrm{g} / \mathrm{ml}$ sebesar $91,95 \%$ dan 1000 $\mu \mathrm{g} / \mathrm{ml}$ sebesar $100 \%$ Walaupun fraksi air pada konsentrasi $1000 \mu \mathrm{g} / \mathrm{ml}$ memiliki persentase penghambatan yang sama dengan fraksi etil asetat yaitu sebesar $100 \%$ tetapi pada konsentrasi $10 \mu \mathrm{g} / \mathrm{ml}$ dan $100 \mu \mathrm{g} / \mathrm{ml}$ fraksi etil asetat memilki persentase penghambatan yang labih besar dibandingkan dengan fraksi air. Oleh karena itu, fraksi etil asetat lebih efektif dibandingkan fraksi air.

Dari hasil persentase penghambatannya, fraksi etil asetat memiliki persentase penghambatan yang lebih baik dibandingkan dengan asam askorbat yang dijadikan sebagai pembanding pada pegujian ini. Pada konsentrasi $100 \mu \mathrm{g} / \mathrm{ml}$ fraksi etil asetat telah memberikan presentase inhibisi sebesar 91,95\% sedangkan pada asam askorbat dengan konsentrasi terbesar yang diuji yaitu sebesar $176,13 \mu \mathrm{g} / \mathrm{ml}$ memberikan presentase penghambatan yang lebih kecil yaitu sebesar $81,48 \%$.

\section{KESIMPULAN DAN SARAN \\ Kesimpulan}

Berdasarkan hasil pengujian aktivitas antioksidan dengan penghambatan reduksi WST-1 menunjukkan bahwa ekstrak etanol daun A.hispida memiliki aktivitas antioksidan (SOD like activity) dengan persentase penghambatan pada konsentrasi 10 $\mu \mathrm{g} / \mathrm{ml}, 100 \mu \mathrm{g} / \mathrm{ml}$, dan $1000 \mu \mathrm{g} / \mathrm{ml}$, yaitu sebesar 11,27\%, 15,20\% dan 22,06\%.

Fraksi ekstrak etanol daun $A$. hispida yang memiliki aktivitas antioksidan (SOD like activity) terbaik adalah fraksi etil asetat dengan persentase penghambatan pada konsentrasi $10 \mu \mathrm{g} / \mathrm{ml}, 100 \mu \mathrm{g} / \mathrm{ml}$, dan $1000 \mu \mathrm{g} / \mathrm{ml}$, yaitu sebesar $63,14 \%$, 91,95\%dan $100 \%$.

\section{Saran}

Berdasarkan hasil penelitian ini maka disarankan untuk melakukan penelitian lebih lanjut mengenai isolasi senyawa aktif dari senyawa yang memiliki aktivitas antioksidan terbaik. 
Selain itu, pengujian aktivitas antioksidan sebaiknya dilakukan dengan variasi konsentrasi yang lebih kecil dan tidak terlalu jauh sehingga aktivitas antioksidan yang didapatkan akan lebih maksimal.

\section{DAFTAR PUSTAKA}

Adesina, S.K., Idowu, O., Ogundaina, A.O., Oladimeji, H., Olugbade, T.A., Onawunmi, G.O. and Pais, M. 2000. Antimicrobial constituents of leaves of Acalypha wikesiana and Acalyphahispida. Phytother 14: 371374.

Gutierrez-Lugo M.T., Singh M.P., Maiese W.M., and Timmermann B.N. 2002.New antimicrobial cycloartane triterpenes from Acalyphacommunis.J Nat Prod 65: 872-875.

Okondoru, S., T. Sokari, M. Okondoru and E. Chinakwe, 2009.Phytochemical and antibacterial properties of Acalypha hispida leaves. Int. J. Nat. Applied Sci., 5: 38-45

Onocha,P.A., Oloyede, G.K.,andAfolabi, Q.O.2011.Phytochemical Investigation, Cytotoxicity and Free Radical Scavenging Activities of Non-Polar Fractions of Acalypha Hispida (Leaves And Twigs). Excli Journal ;10:1-8
Parwata, A., Ratnayani, K., dan Listya, A. (2010). Aktivitas Antiradikal Bebas Serta Kadar Beta Karoten Pada Madu Randu (Ceiba Pentandra) Dan Madu Kelengkeng (Nephelium Longata L.). Jurnal Kimia FMIPA Universitas Udayana

Potterat, O. 1997. Antioxidants \& Free Radical Scavengers of Natural Origin. Current OrganicChemistry 1,415 - 440. 